\title{
PROPENSITY TO CUSTOMER SWITCHING: A REVIEW ON APPAREL STORES
}

Chaminda Karunaratna'

University of Ruhuna, Matara, Sri Lanka

\section{ABSTRACT}

In the contemporary marketplace, customer switching has become a popularly addressed phenomenon. This study endeavoured to provide an approach to understand the customer switching behaviour and identify the major factors which influence customer switching in apparel stores. Clothing has become a major requirement for each and every customer in this modern society. Customers use their preferred brand, material and style etc. and become loyal to particular apparel store/s where they can enjoy the expected benefits in choosing preferred clothing items. However, customers may switch their apparel stores due to various reasons. Even though many clothing brands at different quality and price levels are available, many customers still switch among different apparel stores. In the field of apparel industry, researchers have put more weight on the fashion clothing, nature of purchasing decisions, and clothing brand loyalty etc. However, the research studies which focus on customer switching is scarce. Therefore, this study attempts to study the factors which cause customer switching in appreal stores. The survey method was adopted as the main research method to conduct the study. The sample consisted of 300 customers who were met at their visits to textile shops in the city of Matara in Sri Lanka. An exploratory factor analysis was employed to identify the major factors of customer switching. According to the results of the exploratory factor analysis, five major factors such as inferior quality, unavailability, service failure, stressful atmosphere and high price were identified as the major factors which influence the switching decision in retail apparel store.

\section{JEL CLASSIFICATION \& KEYWORDS}

M3 - M31 - M310 $\because$ APPAREL $\backsim$ ATMOSPHERE $\backsim$ PRICE - QUALITY $\approx$ SWITCHING

\section{INTRODUCTION}

Understanding consumer behaviour is momentous in the marketing context, especially at the current dynamic marketplace. Marketers have drawn a significant attention on retaining customers since it is critical for the success of a company. Customer retention is exceptionally important because acquiring a new customer is far more expensive than keeping an existing one (Ang \& Buttle, 2005; Zeithaml, Berry \& Parasuraman, 1996; Reichheld \& Kenny, 1990). Thus, customer retention has become a major goal for many businesses (Ennew, Binks \& Chiplin, 2015; Terblanche \& Hofmeyr, 2005). Meanwhile, Lemon, White \& Winer (2002) express that the trend in marketing towards building relationships with customers continues to grow, and marketers have become increasingly interested in retaining customers over long-term.

Thus, in this context it is essential to understand the expectations of customers and become committed to fulfil customer requirements profitably. Some of customers' ' acruhuna@gmail.com

www.journals.cz expectations can be identified as results of their characteristics of consumer behaviour that have changed over time (Fralix, 2001). Although customer retention is an essential goal, customer defection rate is also very high in the competitive business domain. Many companies, specially retail firms and service organizations face a huge challenge in retaining customers due to higher rate of customers switching. Therefore, in the contemporary marketplace, customer switching has become a popularly addressed phenomenon and the marketing literature is replete with studies evaluating the nature of the customer switching (Keaveney, 1995; Bansal \& Taylor, 1999; Patterson and Smith, 2003; Pric, 2006; Wieringa \& Verhoef, 2007; Vyas \& Raitani, 2013). The author has developed a model as illustrated in figure 1 which shows customer choice between the retention and switching. Specially, in the retailing business context shoppers may leave retail shop without purchasing their required consumption items due to various reasons. This study focused on identifying why customers leave an apparel store without purchasing their required clothing items. Every person today wears clothes either as a basic need fulfillment or a fashion. However, they will not purchase the required apparel item at their first visit. Besides they would visit several shops finding and comparing alternative apparel items in terms of quality, material, brand and price etc. Accordingly, this study endeavoured to provide an approach to understand the customer switching behaviour and identify the major factors which influence customer switching in an apparel store without purchasing the required apparel item(s).

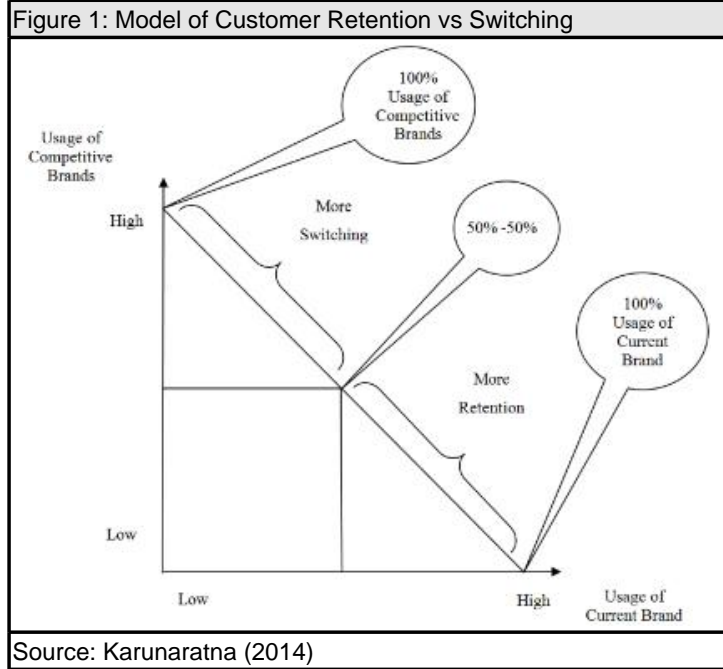

Problem Statement

In analysing basic customer needs, clothing has become major requirement for each and every customer. This can be considered as one of most important basic needs of 
human beings. However, in this global village the purpose of usage of clothing has become more diverse. Many people use clothing as a fashion while some use to represent their social status. When considering different customer groups, their clothing patterns, styles, and appearance are different with their nationality, religion, social class, gender, and age etc. Apparel market is quite healthy today with both imported and local clothes. At the same time, the places where customers can visit and purchase clothes have become enormously increased while each and every small city is filled with a number of apparel stores where reputed clothing brands, both locally and imported, are available. Customers use their preferred brand, material and style etc. and become loyal to particular apparel store/s where they can enjoy the expected benefits in choosing preferred clothing items. Even though many clothing brands at different quality and price level are available, many customers still switch among different apparel stores without making a purchase. Customers may not purchase clothes due to different kinds of reasons such as inconvenience, unfair pricing practices, inadequate service and poor sales staff etc. Further, customers will be persuaded to leave the existing brand and stick to other competitive brands due to attractive offers provided by competitors (Keaveney, 1995). However, in the field of apparel industry, researchers have put more weight on the fashion clothing (for instance: Lin \& Xia, 2012; Diaz-Meneses, 2010; Apeagyei, 2007), nature of purchasing decisions (for instance: De Klerk \& Tselepis, 2007; Fadiga, Misra \& Ramirez, 2005), clothing brand loyalty (for instance: Oh \& Fiorito, 2002;), the research studies which focus on customer switching is scarce. Therefore, this study attempts to study the factors which cause customer switching in appreal stores.

\section{Literature Review}

The twofold goal in marketing is customer attraction and retention (Kotler \& Keller, 2011). However, in the current competitive business context, this goal of customer retention has become a huge challenge since customers tend to switch among different brands due to different reasons. Customers switch among different brands seeking attractive offers, more benefits, and lower prices etc. At the same time, competitors are also looking for attracting competitors' customers due to intense competition. Therefore, many scholars have addressed this issue of customer switching and the marketing literature is rich with studies in customer switching. (for instance, see Keaveney, 1995; Bansal \& Taylor, 1999; Jonathan, Janghyuk \& Lawrence, 2001; Patterson \& Smith, 2003; Pric, 2006; Wieringa \& Verhoef, 2007; Oyeniyi \& Abiodun, 2010; Vyas \& Raitani, 2013; Karunaratna, 2014).

Keaveney (1995) has conducted an exploratory study on customer switching behaviour in service industry including forty-five types of services. Accordingly, she has identified eight major factors and forty-eight variables which cause customer switching in the services industry. According to the study by Keaveney (1995), core service failure is the largest category (by $44 \%$ of respondents) which influences switching. These core service failures include mistakes, billing errors and service catastrophes. Service encounter failures defined as personal interactions between customers and employees of service firms is reported as the second largest category for switching. These service encounter failures include uncaring, impoliteness, unresponsiveness, and unknowledgeability. These failures attributed to some aspect of behaviours or attitudes of employees. The attitudes and behaviour patterns of employees play a significant role in delivering effective service due to intangibility nature of the service. Pricing has recorded as the third largest switching category (by $30 \%$ of respondents). The inconvenience is another important factor which causes customer switching. Customers have felt inconvenience by the service provider's location, hours of operation, waiting time for service, or waiting time to get an appointment. According to Keaveney (1995), the next important factor, which causes customer switching, includes employee responses to service failures. This category includes critical switching incidents not because of a service failure, but service providers' failures to handle the situation in an appropriate manner. Eshghi, Haughton \& Topi, (2007) investigating the determinants of the propensity to switch wireless service providers, reports that until a few years ago, wireless telephone customers in the United States have faced significant costs in switching from one wireless service provider to another because doing so would have meant the loss of a phone number known by friends, relatives and business associates. As a result, a vast majority of customers have tended to stay with their wireless service provider regardless of their satisfaction with the service. Patterson \& Smith (2003) have explored the switching barriers and propensity to stay with service providers by a cross-cultural study across two diverse cultures, Australia (Western, individualistic culture) and Thailand (Eastern, collectivist culture). Six potential switching barriers such as search costs, loss of social bonds, setup costs, functional risk, attractiveness of alternatives, and loss of special treatment benefits have been examined.

Pirc (2006) admits that understanding customer propensity to react to competitors marketing actions to switch can provide valuable insight in the study of determinants of relationship maintenance and customer loyalty. Hence, he defines customer propensity to switch as the expressed likelihood by the customer of positively reacting to competitors' offers. Pric (2006) has conducted an empirical study to investigate the role and influence of the product (mobile phone) as a part of consumption-system on customer loyalty and customer switching intentions to mobile service providers. According to Pric (2006), mobile service usage has a curvilinear effect on propensity to switch. Regarding the propensity to switch service providers, the mobile service budgetary constraint has also influenced while mobile phone budgetary constraint and income have not influenced. Therefore, he states that when addressing customer from the price perspective, the service price should put adjusted and not the mobile phone prices as customers think in mental accounts terms. The length of experience and type of the service whether contract or prepaid, have not played an important role. It is reported that involvement in mobile services and mobile phone purchase involvements drive up the risk of customer leaving. When a customer left a brand, it would not be easy to turn him back in.

Ahmad \& Buttle (2001) present six types of defectors identified by DeSouza (1992), such as price - for a lower price, product - for a superior product, service - for a better service, market - for a different market, technological - a customer that has converted from using one technology to another, organizational -switches due to political pressure. Bitner (1990) has conducted an empirical research study to investigate reasons that cause customer loyalty due to lack of ability to switch. According to Bitner (1990), those key factors are time or money constraints, lack of alternatives, switching costs, and habit. However, in the field of apparel industry, researchers have put more weight on the fashion clothing (for instance: Lin \& Xia, 2012; Diaz-Meneses, 2010; Apeagyei, 2007; Grant \& Stephen, 2005; Rocha, Hammond 
\& Hawkins, 2005), nature of purchasing decisions (for instance: De Klerk \& Tselepis, 2007; Fadiga, Misra \& Ramirez, 2005), clothing brand loyalty (for instance: Oh \& Fiorito, 2002;), the research studies which focus on customer switching is scarce. Kurt Salmon Associates (2000) has introduced ten major reasons for customers' switch an apparel store without having a purchase. Those can be identified as cannot find an appealing style, cannot find the right size, the item is out of stock, nothing fits, no sales help is available, cannot get in and out of the store easily, prices are too high, in-store experience is stressful, cannot find a good value, store is not merchandised conveniently, seasonality is off.

\section{Methodology}

Customer switching has become a major issue at the current competitive business context. It is a critical factor to address the issue why customers leave a retail store without making a purchase. Thus, most of scholars have addressed this concept in the marketing literature (Keaveney, 1995; Vyas \& Raitani, 2013; Lianjv \& Xin, 2014; Manrai \& Manrai, 2015). Especially, customer switching has been paid a considerable attention in the consumer behaviour studies since marketers face a huge challenge for their long-term survival and growth due to this high tendency of customer switching. Since this has become a key issue, this study attempts to identify the factors affecting switching decisions in the field of apparel industry. Kurt Salmon Associates (2000) has identified ten factors such as cannot find the quality items, cannot find an appealing style, cannot find the right size, the item is out of stock, nothing fits, no sales help is available, cannot get in and out of the store easily, prices are too high, in-store experience is stressful, cannot find a good value, store is not merchandised conveniently, seasonality is off which influence on customer switching without making purchases. Survey method was used as the main research method to conduct the study. Convenience sampling was used as the sampling technique and 300 customers were met at their visits to textile shops in the city of Matara in the Southern province in Sri Lanka.

\section{Results and Discussion}

The objective of the study was to identify the major factors why customers switch from one shop to another in the apparel industry without making a purchase. As such twelve customer response variables were identified. As a data reduction technique, Exploratory Factor analysis was employed to identify the underlying factors which cause customer switching. KMO measure of sampling adequacy for the items is 0.690 and Bartlett's test value is statistically significant (Chi-square $=2384.857, \mathrm{P}<0.000$ ) indicating adequacy of inter-correlations among the items.

\begin{tabular}{|l|l|}
\hline Table 1: Communalities & Extraction \\
\hline Not in right quality & 0.985 \\
\hline Not in right size & 0.99 \\
\hline Not in appealing style & 0.349 \\
\hline Item is out of stock & 0.731 \\
\hline Nothing fits & 0.786 \\
\hline No sales help is available & 0.507 \\
\hline Can not get in and out of the store easily & 0.629 \\
\hline Prices are too high & 0.621 \\
\hline Perceive unfair pricing & 0.61 \\
\hline In-store experience is stressful & 0.636 \\
\hline No good value for money & 0.973 \\
\hline Store is not merchandized conveniently & 0.654 \\
\hline Source: Author & \\
\hline
\end{tabular}

www.journals.cz
The table 1 shows the communalities which show that how much of variance in in each of the item is explained by the extracted factors. Accordingly, three items have been reported above 0.9 while two items reported above 0.7 . There is only single item which has reported below 0.5 where all other items reported above 0.5 .

Table 2 shows the results of the Rotated Factor Matrix. The results show that the twelve variables can be classified into five major dimensions. According to the results of the exploratory factor analysis, five major factors such as inferior quality, unavailability, service failure, stressful atmosphere and high price were identified as the major factors which influence the switching decision in retail apparel store.

\begin{tabular}{|l|l|l|l|l|l|}
\hline Table 2: Rotated Factor Matrix & \multicolumn{5}{|c|}{ Component } \\
\hline & 1 & 2 & 3 & 4 & 5 \\
\hline Not in right size & 0.994 & & & & \\
\hline Not in right quality & 0.992 & & & & \\
\hline No good value for money & 0.986 & & & & \\
\hline Nothing fits & & 0.875 & & & \\
\hline Item is out of stock & & 0.833 & & & \\
\hline Not in appealing style & & 0.48 & & & \\
\hline Store is not merchandized conveniently & & & 0.804 & & \\
\hline No sales help is available & & & 0.694 & & \\
\hline Prices are too high & & & & 0.78 & \\
\hline Perceive unfair pricing & & & & 0.771 & \\
\hline In-store experience is stressful & & & & & 0.771 \\
\hline Can not get in and out of the store easily & & & & & 0.765 \\
\hline Source: Author & & & & \\
\hline
\end{tabular}

Based on this outcome, the researcher provides the following conceptual framework as shown in figure 2 which portrays the factors for switching.



As figure 2 illustrated, five switching dimensions were identified with respect to the switching intension of the apparel stores. Customer responses for each dimension were evaluated with Mean and Standard Deviations as shown in table 3 to evaluate the nature of the switching dimensions.

\begin{tabular}{|l|l|l|}
\hline Table 3: Mean and Standard Deviation of Switching Dimensions \\
\hline Dimension & Mean Value & Standard Deviation \\
\hline Inferior Quality & 4.25 & 0.34 \\
\hline Unavailability & 4.21 & 0.31 \\
\hline Service Failure & 4.18 & 0.33 \\
\hline Stressful Atmosphere & 4.5 & 0.36 \\
\hline High Price & 4.01 & 0.14 \\
\hline Source: Author
\end{tabular}

Table 3 shows that all the switching dimensions identified in this study have reported Mean value above 4.00. 
According to the table 3 , stressful atmosphere which indicates the highest mean value of 4.50 has become the major switching dimension. Therefore, it is timely need to reduce the stress encountered by the customers and guarantee the convenience to provide a better service for their customers. Inferior quality was identified as the next important switching dimension. It is obvious that customers expect good value for their money spent and quality clothing materials with appropriate sizes, because people would prefer to wear quality clothing materials to keep them comfortable. Apparently, unavailability is also treated as a major factor for switching. Consumers might visit apparel store expecting their preferred clothing material with desired attributes. If those are not available, most probably they may switch.

\begin{tabular}{|l|l|l|l|l|l|}
\hline \multicolumn{6}{|l|}{$\begin{array}{l}\text { Table 4: Mean Comparison of Female versus Male for Switching } \\
\text { Dimensions }\end{array}$} \\
\hline Variable & $\begin{array}{c}\text { Mean } \\
\text { (Female) }\end{array}$ & $\begin{array}{c}\text { Mean } \\
\text { (Male) }\end{array}$ & $\begin{array}{c}\text { Mean } \\
\text { Difference }\end{array}$ & t Value & $\begin{array}{c}\text { Significance } \\
\text { Level }\end{array}$ \\
\hline $\begin{array}{l}\text { Inferior } \\
\text { Quality }\end{array}$ & 4.27 & 4.24 & 0.03 & 0.876 & 0.382 \\
\hline Unavailability & 4.21 & 4.21 & 0 & 0.012 & 0.991 \\
\hline $\begin{array}{l}\text { Service } \\
\text { Failure }\end{array}$ & 4.24 & 4.14 & 0.01 & 2.49 & 0.013 \\
\hline $\begin{array}{l}\text { Stressful } \\
\text { Atmosphere }\end{array}$ & 4.52 & 4.49 & 0.03 & 0.511 & 0.61 \\
\hline $\begin{array}{l}\text { High Price } \\
\text { Source: Author }\end{array} 4.02$ & 4 & 0.02 & 0.515 & 0.607 \\
\hline
\end{tabular}

Table 4 shows the Mean comparison of female versus male for switching dimensions. It was tested whether customers' perceptions towards switching differ in terms of gender base. However, the results show that both male and female customers have high level of perception indicating above 4.0 Mean value. Anyway, no significant difference existed between male customers and female customers in the case of apparel switching.

\begin{tabular}{|c|c|c|c|}
\hline \multicolumn{4}{|c|}{$\begin{array}{l}\text { Table 5: Comparison of Consumer Responses by Gender, Age an } \\
\text { Education }\end{array}$} \\
\hline Variable & Value & $\mathrm{F}$ & Sig. \\
\hline \multicolumn{4}{|l|}{ Gender } \\
\hline Pillai's Trace & 0.03 & 1.786 & 0.116 \\
\hline Wilks' Lambda & 0.97 & 1.786 & 0.116 \\
\hline Hotelling's Trace & 0.031 & 1.786 & 0.116 \\
\hline Roy's Largest Root & 0.031 & 1.786 & 0.116 \\
\hline \multicolumn{4}{|l|}{ Age } \\
\hline Pillai's Trace & 0.156 & 1.871 & 0.006 \\
\hline Wilks' Lambda & 0.851 & 1.884 & 0.006 \\
\hline Hotelling's Trace & 0.166 & 1.886 & 0.005 \\
\hline Roy's Largest Root & 0.09 & 5.207 & 0 \\
\hline \multicolumn{4}{|l|}{ Education } \\
\hline Pillai's Trace & 0.074 & 1.46 & 0.114 \\
\hline Wilks' Lambda & 0.927 & 1.462 & 0.113 \\
\hline Hotelling's Trace & 0.077 & 1.462 & 0.113 \\
\hline Roy's Largest Root & 0.09 & 2.778 & 0.018 \\
\hline
\end{tabular}

GLM statistics were evaluated for gender, age and education which are shown in Table 5. According to the results, gender has not significantly impacted on switching decisions. It confirms the t-test results that all the tests denoting no significant differences between male and female consumers. Further, it could be noted that education has also not significantly impacted on the switching decisions and no different educational background made an effect on the decisions. However, age is decisive and it has a significant impact on switching intention which is confirmed by all four tests of Pillai's Trace, Wilks' Lambda, Hotelling's Trace, and Roy's Largest Root as shown in table 5.

\begin{tabular}{|c|c|c|}
\hline Variable & Set 1 & Set 2 \\
\hline \multicolumn{3}{|l|}{ Inferior Quality } \\
\hline Between $30-34$ & 4.175 & \\
\hline Below 20 & 4.233 & 4.233 \\
\hline Between $20-24$ & 4.313 & 4.313 \\
\hline Between 25-29 & 4.229 & 4.229 \\
\hline Between $35-39$ & 4.241 & 4.241 \\
\hline Above 40 & 0.14 & 4.378 \\
\hline Sig. & & 0.108 \\
\hline \multicolumn{3}{|l|}{ Unavailability } \\
\hline Below 20 & 4.05 & \\
\hline Between $20-24$ & 4.191 & 4.191 \\
\hline Between $25-29$ & 4.2 & 4.2 \\
\hline Above 40 & 4.167 & 4.167 \\
\hline Between $30-34$ & & 4.316 \\
\hline Between $35-39$ & & 4.218 \\
\hline Sig. & 0.058 & 0.066 \\
\hline \multicolumn{3}{|l|}{ Service Failure } \\
\hline Above 40 & 4.045 & \\
\hline Between 35-39 & 4.103 & \\
\hline Below 20 & 4.175 & 4.175 \\
\hline Between $20-24$ & 4.201 & 4.201 \\
\hline Between 25-29 & 4.167 & 4.167 \\
\hline Between $30-34$ & & 4.281 \\
\hline Sig. & 0.07 & 0.178 \\
\hline \multicolumn{3}{|l|}{ High Price } \\
\hline Below 20 & 3.95 & \\
\hline Between $20-24$ & 4.012 & 4.012 \\
\hline Between $25-29$ & 4.011 & 4.011 \\
\hline Between $30-34$ & 4 & 4 \\
\hline Between $35-39$ & 4 & 4 \\
\hline Above 40 & & 4.045 \\
\hline Sig. & 0.101 & 0.236 \\
\hline Source: Author & & \\
\hline
\end{tabular}

Table 6 shows the results of the Duncan test for the five factors identified. Results show that customers in the age category of 30-34 fall in the first set while customers above 40 years fall in the second set. According to the mean values (30-34 years: 4.175 , above 40 years: 4.378$)$, customers above 40 years have slightly higher perception of inferior quality than those are in the 30-34 age category. Customers in the age categories between $30-34$ and $35-39$ years have higher perception towards unavailability. With respect to the service failure, customers in the age group of 30-34 have slightly higher perception as well. Compared to the teen agers customers who are above the age 40 years have slightly higher perception towards high price. Therefore, it could be noted that middle aged customers and elderly customers have a bit higher perception which is drawn for the decision of switching compared to the young customers.

Results of the Duncan test as illustrated in table 6 show that customer perceptions have slight differences among the different age groups. This could be further examined with the results in the table 7 . While the model becomes 
significant, a few changes could be observed with respect to the gender and age. For instance, the perception of service failure is different between male and female customers. At the same time, perception of availability and service failure depend on age as well. Therefore, gender and age play a fascinating role in consumer decision making process.

\begin{tabular}{|c|c|c|c|c|}
\hline Source & Variable & Mean Square & $\mathrm{F}$ & Sig. \\
\hline \multirow{5}{*}{ Model } & Inferior Quality & 543.165 & 4571.348 & 0 \\
\hline & Unavailability & 531.582 & 5790.999 & 0 \\
\hline & Service Failure & 525.27 & 5112.427 & 0 \\
\hline & High Price & 481.625 & 24269.913 & 0 \\
\hline & Stressful Atmosphere & 608.54 & 4632.112 & 0 \\
\hline \multirow{5}{*}{ Gender } & Inferior Quality & 0.084 & 0.705 & 0.402 \\
\hline & Unavailability & 0.003 & 0.033 & 0.856 \\
\hline & Service Failure & 0.715 & 6.957 & 0.009 \\
\hline & High Price & 0.012 & 0.62 & 0.432 \\
\hline & Stressful Atmosphere & 0.024 & 0.183 & 0.67 \\
\hline \multirow{5}{*}{ Age } & Inferior Quality & 0.195 & 1.645 & 0.148 \\
\hline & Unavailability & 0.213 & 2.318 & 0.044 \\
\hline & Service Failure & 0.325 & 3.167 & 0.008 \\
\hline & High Price & 0.019 & 0.971 & 0.436 \\
\hline & Stressful Atmosphere & 0.233 & 1.774 & 0.118 \\
\hline \multirow{5}{*}{ Education } & Inferior Quality & 0.135 & 1.137 & 0.334 \\
\hline & Unavailability & 0.056 & 0.61 & 0.609 \\
\hline & Service Failure & 0.217 & 2.112 & 0.099 \\
\hline & High Price & 0.04 & 1.991 & 0.115 \\
\hline & Stressful Atmosphere & 0.118 & 0.898 & 0.442 \\
\hline
\end{tabular}

\section{CONCLUSION}

Customer switching has become a fascinating topic in the field of consumer behaviour. Therefore, in the contemporary marketplace, customer switching has become a popularly addressed phenomenon. This study focused on developing an approach to understand the customer switching behaviour and identify the major factors which influence customer switching with respect to the apparel stores since clothing has become a major requirement for each and every customer in this modern society. The survey method was adopted as the main research method to conduct the study. The sample consisted of 300 customers who were met at their visits to textile shops in the city of Matara in the Southern province in Sri Lanka. An exploratory factor analysis was employed to identify the major factors of customer switching. According to the results of the exploratory factor analysis, five major factors such as inferior quality, unavailability, service failure, stressful atmosphere and high price were identified as the major factors which influence the switching decision in retail apparel store. At the same time, gender and age were also identified as decisive factors which influence in consumer decisions making.

\section{REFERENCES}

Ahmad, R. \& Buttle, F. (2001). Customer retention: a potentially potent marketing management strategy, Journal of Strategic Marketing, 9, 29-45.

Ang, L., \& Buttle, F. (2005). Customer retention management processes: A quantitative study. European Journal of Marketing, 40, 83-89.

Apeagyei, P.R. (2007). Significance of body image among UK female fashion consumers: The cult of size zero, the skinny trend. www.journals.cz
International Journal of Fashion Design, Technology and Education, 1 (1), 3-11.

Bansal, H.S. \& Taylor, S.F. (1999). The Service Provider Switching Model (SPSM): A Model of Consumer Switching Behaviour in the Services Industry. Journal of Service Research, 2 (2), 200-218.

Bitner, M. Jo (1990). Evaluating Service Encounters: The Effects of Physical Surroundings and Employee Responses. Journal of Marketing, 54, 69-82.

Diaz-Meneses, G. (2010). The Ethics of Consumer Involvement with Fashion: A Freedom under Social Pressure. Textile Research Journal 80 (4), 354-364.

De Klerk, H. M. \& Tselepis, T. (2007). The early-adolescent female clothing consumer: Expectations, evaluation and satisfaction with fit as part of the appreciation of clothing quality. Journal of Fashion Marketing and Management, 11 (3), 413-428.

Ennew, C. T., Binks, M. R., \& Chiplin, B. (2015). Customer Satisfaction and Customer Retention: An Examination of Small Businesses and Their Banks in the UK. In Proceedings of the Academy of Marketing Science, Springer International Publishing, 188-192.

Eshghi, A., Haughton, D, and Topi H. (2007). Determinants of customer loyalty in the wireless telecommunications industry. Telecommunications Policy, 31 (2), 93-106.

Fadiga, M. L., Misra S. K., \& Ramirez, O. A. (2005). US consumer purchasing decisions and demand for apparel. Journal of Fashion Marketing and Management, 9 (4), 367-379.

Fralix, M. T., (2001). From Mass Production to Mass Customization. Journal of Textile and Apparel, Technology and Management, 1 (2), $1-7$.

Grant, I. J. \& Stephen, G. R. (2005). Buying behaviour of tweenage girls and key societal communicating factors influencing their purchasing of fashion clothing. Journal of Fashion Marketing and Management, 9 (4), 450-467.

Jonathan. L., Janghyuk, L., \& Lawrence F. (2001). The impact of switching costs on the customer satisfaction-loyalty link: mobile phone service in France. Journal of Services Marketing, 15 (1), 35-48. Karunaratna, A.C. (2014). Why Customers Switch: Evidence from Mobile Phone Service Industry. Asia-Pacific Marketing Review, 3 (1), 37-46.

Keaveney, S. M. (1995). Customer Switching Behaviour in Service Industries: An Exploratory Study, Journal of Marketing, 59 (2), 71-82.

Kotler, P. \& Keller, K.L. (2011). Marketing Management, PrenticeHall, New Jersey.

Kurt Salmon Associates, (2000). Which Way to the Emerald City?, Perspective, p. 03

Lianjv, A., \& Xin, F. (2014). The Switching Chices of Subscribers in China Mobile Market. TEL KOMNIKA Indonesian Journal of Electrica Enginerring, 12 (2), 1416-1423.

Lemon, N.L., White, T.B., \& Winer, R.S. (2002). Dynamic Customer Relationship Management: Incorporating Future Considerations into the Service Retention Decision. Journal of Marketing, 1-14.

Lin, Y. \& Xia, K. (2012). Cognitive age and fashion consumption International Journal of Consumer Studies, 36, 97-105.

Manrai, A. K., \& Manrai, L. A. (2015). Consumer Switching Behaviour of Banking Services: A Conceptual Model. Developments of Marketing Science: Proceedings of the Academy of Marketing Science, 106-110

Oh, J \& Fiorito, S. S. (2002). Korean women's clothing brand loyalty. Journal of Fashion Marketing and Management, 6 (3), 206-222.

Oyeniyi, J. O. \& Abiodun, J. A. (2010). Switching Cost and Customers Loyalty in the Mobile Phone Market: The Nigerian Experience. Business Intelligence Journal, 3 (1), 111-121.

Patterson, P. G. \& Smith, T. (2003). A cross-cultural study of switching barriers and propensity to stay with service providers, Journal of Retailing, 79, 107-120.

Pric, M. (2006). Mobile Service and Phone as Consumption Systemthe Impact on Customer Switching, Proceedings of Helsinki Mobility Roundtable Sprouts: Working Papers on Information Systems, 6:33. 
Reichheld, F.F. \& Kenny, D.W. (1990). The hidden advantages of customer retention. Journal of Retail Banking, 12 (4), 19-23.

Rocha, M. A. V., Hammond, L. \& Hawkins, D. (2005). Age, gender and national factors in fashion consumption. Journal of Fashion Marketing and Management, 9 (4), 380-390.

Terblanche, N. S. \& Hofmeyr, J. (2005). A Study of Two Customer Retention Measures: The American Customer Satisfaction Index And The Conversion Model. ANZMAC Conference: Relationship Marketing.

Vyas, V. \& Raitani, S. (2014). Drivers of customers' switching behaviour in Indian banking industry. International journal of Bank Marketing, 32 (4), 321-342.

Wieringa, J.E. \& Verhoef, P.C. (2007). Understanding Customer Switching Behaviour in Liberalizing Service Market: An Exploratory Study. Journal of Service Research. 10 (2), 174-186.

Zeithaml, V. A., Berry, L. L., \& Parasuraman, A. (1996). The Behavioural Consequences of Service Quality. Journal of Marketing, $60,31-46$. 